Article

\title{
Accommodating Multilingualism in Macedonia
}

\author{
Renata Treneska-Deskoska \\ lustinianus Primus Faculty of Law, Ss. Cyril and Methodius University, 1000 Skopje, Macedonia; \\ E-Mail: renatadeskoska@gmail.com
}

Submitted: 14 August 2017 | Accepted: 17 October 2017 | Published: 22 December 2017

\begin{abstract}
The period since the independence of the Republic of Macedonia in 1991 has shown the political importance of language, as well as the political tensions that can arise over language-related issues. For a long time, multilingualism in Macedonia was a problem that threatened the unity and stability of the country. In 2001 the armed conflict in Macedonia showed that governmental policies of ignoring certain issues fueled ethnic divisions and facilitated a climate of insecurity. In order to terminate the armed conflict, Macedonia has since introduced constitutional changes relevant to linguistic diversity. The constitutional amendment regulating the official use of languages in Macedonia was as a result of a necessary compromise to terminate the armed conflict. The amendment is formulated in a vague and contradictory manner; full of loopholes, views provided on official languages leads to different interpretations and is still subject to disputes between experts, as well as party leaders in Macedonia. This vagueness led to politicians using the topic of the official use of languages as a talking point in every electoral campaign since 2001. This article will examine the challenges and possibilities that came from the constitutional amendment on the use of languages in Macedonia. It will also analyze the loopholes of the legal norms on the use of languages, and the problems of its implementation.
\end{abstract}

\section{Keywords}

ethnic rights; language policy; language rights; Macedonia; multilingualism; official language

\section{Issue}

This article is part of the issue "Multilingualism and Social Inclusion”, edited by László Marácz (University of Amsterdam, The Netherlands/Gumilyov Eurasian National University, Kazakhstan) and Silvia Adamo (University of Copenhagen, Denmark).

(C) 2017 by the author; licensee Cogitatio (Lisbon, Portugal). This article is licensed under a Creative Commons Attribution 4.0 International License (CC BY).

\section{Introduction}

Ethnic questions have been part of the central issue of politics in Macedonia since its independence in 1991. As is the case with other Balkan states, Macedonia has had difficulties in learning that "the failure to carefully protect the rights of minority groups greatly jeopardizes the integrity of the state and the stability of the democratic processes" (Kolarova, 1993, p. 23).

Macedonia struggled with the challenge to grant ethnic rights, and to preserve state sovereignty and territorial integrity. The reconciliation of these "divergent objectives is imperative to resolving tension between minorities and majorities in [the] state-centered world we live in" (Porter, 2003, p. 53).

The ethnic issues have been a major point of friction in Macedonia due to the belief that "[r]ecognition, protection and promotion of minority rights is more than symbolism, as it alters the inherent social, economic and political relations of power between the majority and minorities," prevailed in the political discourse (Tully, 2001, p. 15). In Macedonia, the conflict between Macedonians and Albanians "has tended to focus on the legal and political status of the Albanian population and on the political and cultural character of the Macedonian state" (Engström, 2002, p. 6). There was a dominant fear that the granting of ethnic rights would change the status of Albanians and could threaten the unity and stability of the country.

In the debates over ethnic issues in Macedonia, linguistic rights of ethnic communities have taken a central part. The issue of language is very important because:

The language is often central to feelings of community and culture, of tradition and 'belonging' which makes any menace, disrespect or attack on its use or exis- 
tence capable of arousing strong emotions and potential cause of a conflict. (De Varennes, 1997, p. 138)

Thus, language is "a marker of membership in community" and "a possible red flag for intolerance and discrimination". (De Varennes, 1997, p. 138).

However, the psychological effects that language policies have upon individuals should not be minimized. The language is intimately associated with the individual, and:

Language is a particularly easy tool to use in political control. Therefore, when language policies establish boundaries between people and government the effects are likely to be quite significant: alienation, distancing and political impotence. (Perea, 1992, p. 335)

Thus, proper regulation of the use of languages has affects not only on the boundaries between people and governments, but also on the relations between people of different languages:

Achieving harmony and peace among peoples of different languages and cultures has depended on making all peoples feel that they are part of a given political entity, that their existence is not threatened. (Kibbee, 2008, p. 79)

There is no doubt that accommodating multilingualism should be a question of highest political importance in every country today. This issue is an important task for constitutional designers, because:

The failure to manage linguistic conflict through constitutional design has the potential to lead to an escalating set of demands-for official-language status in shared institutions, to territorial autonomy, and ultimately, to secession. (Choudhry, 2009, p. 578)

\section{Official Language-No Single Definition}

In contrast to religion, the state cannot be neutral in choosing the official language. The constitutional designers solve this question in different ways: by choosing one official language; by choosing several official languages with equal scope of use; by giving to some minority languages partial official status in some domains on national level and in some smaller territorial units; or, by giving some minority languages official status on local level. However, there is no universal definition of what an official language means.

The official use of language of the majority is selfimplied because the "state functions may be exercised most efficiently by using the language known to the greatest percentage of the population in a country", but it does not "indicate that establishing the official language (official languages) of a country is considered as an issue of a mere technical or practical relevance" (Korhecz, 2008, p. 460).
The decision of which language becomes the official language of the state has much to do with the power perspective. In nation states, a:

Language of the group in power, became the dominating paradigm for communication with and within the state guaranteeing that specific groups dominating the language of the nation state formation could take control of the state's governance structures. (Marácz, 2014, p. 46)

Marácz explains that the power element is always present in the relationship between majority and minority languages and cases of "linguistic hegemony and multilingual communication that result in far more complicated linguistic and communicational patterns [that] trigger conflicts" which are essentially political.

The language groups not controlling the state language are excluded from power and the groups being excluded from power are struggling for recognition in order to get access to the power structure of the state in their first language. (Marácz, 2014, p. 46)

In addition to this struggle is the recognition that "Ianguage policies are never exclusively about language and are often understood as embedded in wider social, political and economic contexts" (Zappettini \& Comanaru, 2014 , p. 403) and "language use is an element central to constructing domination in organizational settings" (Wodak, Krzyźanowski, \& Forchtner, 2012, p. 158). This will be shown in the Macedonian case of accommodation of multilingualism.

In many countries, there are varying degrees of official use of some minority languages, and the minority language can often be used as the official language in distinct institutional contexts. Alan Patten and Will Kymlicka (2003) provide a useful taxonomy of the distinct institutional contexts in which the choice of official language must be made. The states must choose an official language for legislatures, courts, and the executive. Further distinctions can be made within each of these categories. A further distinction can be drawn between the internal language of government and the language of public services (e.g., education); between procedure in the legislature and in its committees; or the manner of use of minority language in judicial procedures.

Several factors influence the degree of the official use of minority languages, as do:

The number and territorial concentration of individuals belonging to a particular linguistic minority, the status of the minority language historically, long standing ties of a linguistic minority and a particular territory (autochthonous character), the influence and pressure imposed by the kin-state to achieve recognition of the official use of particular minority language, political influence of the minority itself de- 
manding to achieve official status of its language, and the expressed demand and need of speakers to use the minority language, etc. (Korhecz, 2008, p. 464)

All of these factors have influenced the promotion of the official use of the Albanian language in Macedonia. The analysis of the official use of minority languages in Macedonia will also confirm Grin's statement that despite the constitutional positioning of the minority language as official, three conditions must be met for members of language minorities to use their language. These conditions are: capacity, opportunity, and desire (or willingness) (Grin, 2003, pp. 43-44). As minority language-speakers are typically bilingual, people's willingness to use their language depends, among other things, on whether they perceive their language as the most appropriate one to use within a certain institution. "If that is not the case, even the highest level of regional or minority language protection and promotion in the 'legal' domain would then fail to prove effective" (Cardi, 2007, p. 21).

\section{Ethnic Structure and Political Context in Macedonia}

Analysis of the accommodation of multilingualism in Macedonia will consider the "law in context" approach. The methodology that will be followed refers to public policy analysis. The legal and institutional framework of the use of languages will be analyzed. Then, the implementation of the language regime's legal framework will be evaluated and possible policy actions will be considered.

The most recent official numerical data for the ethnic structure of the country are from the last census, held in 2002. Another census was planned for 2011. Parliament adopted the law regulating the tasks of the bodies that were supposed to carry the census, the surveying methodology, etc. The Government appointed twentyfive members of the State Census Commission (SCC). The census started, but four days before the census deadline, all members of the SCC had filed irrevocable resignations, suspending all of its activities because "there are no basic preconditions for continuation of the census", as it "cannot provide relevant data" (Marusic, 2011).

The ethnic Macedonian and Albanian members inside the SCC could not agree on some of the basic rules of the census, and announced that the census had been suspended because different field interpretations of the surveying methodology could not guarantee reliable data (Karajkov, 2011). The difference in the interpretation of the surveying methodology actually influenced the numbers within the ethnic structure of the country.
Some Albanian members are thought to have counted people who had been living abroad for more than a year, as well as accepting photocopies of ID cards as a basis for data. Macedonian members were strongly against this. (Marusic, 2011)

It was clear that the dispute in SCC was ethnically and politically driven, and was not a "scientific" dispute over methodology. In every state the results of the census are the basis for the formation of reforms, road maps, agenda setting and decision making. Moreover, in the case of Macedonia, it was not just a conflict, but also an attempt to manipulate the future agenda. The SCC was not only appointed but also controlled by the Government, i.e., the ruling coalition. The SCC's members that were from DUI-the ruling political party that represented Albanians in Macedonia at the time, chose a methodology that made it possible to strengthen their group representation numerically. The SCC's members that were from VMRO-DPMNE-the ruling party that represented Macedonians, opposed the strategy of DUI. So, the coalition partners in the government decided to "kill the census" in order to give the chance for "the ruling coalition to survive" and continue to lead the government. The resignation of the SCC, supported by methodological explanation, was used as a solution.

According to data from 2002, Macedonia is a country in which Macedonians make up the majority of the population (64.18\%). The largest minority group is Albanian $(25.17 \%)$. There are several other minority groups living in Macedonia, all of which are smaller (the second minority group is Turkish, with $3.85 \%$ of total population) (see Table 1).

The ethnic structure in Macedonia is reflected in its linguistic diversity. The Macedonian language is the mother tongue to $66.49 \%$ of the population; the Albanian language is the mother tongue to $25.12 \%$; Turkish language to $3.55 \%$; Roma language to $1.91 \%$; Serbian language to $1.22 \%$; Bosnian language to $0.42 \%$; Vlach language to $0.34 \%$; and some other languages are mother tongues to $0.95 \%$ of the population.

Most of the ethnic Albanians are compactly settled in the western part of the country in an almost continuous strip along the Macedonian border with Albania and Kosovo, and in some villages near Skopje. From a total of 85 municipalities plus the city of Skopje, Albanians are the majority population in 16 municipalities (from which five are urban and 11 rural) and in 13 units of local self-government, consisting of more than $20 \%$ of the population.

Table 1. Population structure according to national affiliation in 2002 census.

\begin{tabular}{llllllll}
\hline Macedonians & Albanians & Turkish & Roma & Vlachs & Serbs & Bosnians & Others \\
\hline 1297981 & 509,083 & 77,959 & 53,879 & 9,695 & 35,939 & 17,018 & 20,993 \\
\hline $64.18 \%$ & $25.17 \%$ & $3.85 \%$ & $2.66 \%$ & $0.48 \%$ & $1.78 \%$ & $0.84 \%$ & $1.04 \%$ \\
\hline
\end{tabular}

Source: State Statistical Office of the Republic of Macedonia (2002, p. 194). 
Other minorities are not compactly settled, with few exceptions. Turks are the majority in two municipalities and consist of more than $20 \%$ of the population in two other municipalities. Romas are in the majority in one municipality, and Serbs make over $20 \%$ of the population in one rural municipality. What we have in Macedonia today "is continued contact and mutual influence among local languages at local levels" (Friedman, 2012, p. 121).

The Albanians are backed by their kin-state, and this has contributed to a divisive ethnic situation. The influence of the proximity of a kin-state to the readiness of the ethnic communities to demand respect of their rights is already recognized in the existing analysis (De Varennes, 1997, p. 160). But in Macedonia, the proximity of a kin-state of Albanians together with the territorial concentration and number of Albanians in Macedonia, as well as the fight for the independence of Kosovo, raised the fears of the existence of a "hidden agenda for [the] creation of Great Albania" and concerns about the unity of Macedonia.

These fears were fueled by the separatist demands of some Albanian political leaders in the beginning of the transition. Other Albanian political leaders have not addressed the assumptions that they intend to pursue a separatist policy to de-escalate the situation that contributed to inter-ethnic frictions and distrust.

Insecurity and desperation for survival of the Macedonian nation as an independent state in a "hostile neighborhood" also "fueled" the inter-ethnic relations. Since independence, the existence of a Macedonian nation, language, state and church has been denied by neighboring countries: Bulgaria does not accept the existence of the Macedonian language; the Serbian Orthodox Church does not accept the autonomy of the Macedonian Orthodox Church; Greece disputes the right of the country to use its constitutional name and delays or objects to the integration of the country into the international community.

In such political circumstances, Macedonian governments have been among those governments in Eastern Europe and Central Asia for which "language and ethnic diversity are, if not a threat to national unity, at least an inconvenience" (De Varennes, 1997, p. 135).

But despite the ethnic frictions during the period of obtaining independence, "the Macedonian state has nonetheless been more inclusive in terms of its nonMacedonian population than have most other former Yugoslav republics since 1991" (Engström, 2002, p. 6).

One of the reasons for this is due to the multiculturalism and multilingualism that have been present in Macedonia for some time. Macedonia had been a part of Yugoslavia, which consisted of six republics (Serbia, Croatia, Slovenia, Bosnia and Herzegovina, Macedonia, and Montenegro) and had three official languages: Serbo-Croatian, Slovenian, and Macedonian. According to the 1974 Yugoslav Constitution, these three official languages had equal status on a federal level, but in practice the Serbo-Croatian language was dominant in fed- eral institutions. The Constitution also guaranteed the right of national minorities to use their languages in official communication. The Albanian and the Hungarian languages were in official use in the two autonomous regions in Serbia: Kosovo and Vojvodina.

In Macedonia, according to the 1974 Constitution, the Macedonian language was official, and the languages of ethnic minorities were in official use at local level in the municipalities where the minorities were the majority or were in significant number. However, as a result of the wave of nationalism that was present before the dissolution of Yugoslavia, the Constitution of Macedonia was amended in 1989 and limited the linguistic rights of minorities, which led to ethnic frictions and the widespread dissatisfaction of minorities in the process of obtaining independence.

Since independence, Macedonia has been struggling to reconcile the demands of the ethnic communities with the need to be a unitary and indivisible country. In fulfilling that aim in the past, intricate, prolific and sometimes unclear legal norms on the use of languages were adopted. But despite all obstacles and doubts, fostering the rights of ethnic communities is a permanent tendency in Macedonian policies.

\section{Accommodation of Multilingualism in Macedonia in the Period 1991-2001}

The 1991 Macedonian Constitution is characterized by the "promotional" approach:

'Promotional models' are found in states that are characterized by a national majority but where national or ethnic minorities are constitutionally recognized and protected, and, thus, enjoy certain collective rights. (Engl \& Harzl, 2009, p. 311)

According to the 1991 Constitution of the Republic of Macedonia, the Macedonian language, written using its Cyrillic alphabet, is the official language of the Republic of Macedonia. At the time, on the local level, there were two possible situations for the designations of other languages as official. If some ethnic group was the majority in some municipality, its language was also official. If some ethnic group made up at least $20 \%$ of the inhabitants of a municipality, the municipal council could decide to use its language as the official language in that municipality.

Besides this, cultural protection of minorities was guaranteed, as was access to mass media in the minority language, state support to cultural institutions in minority languages, and rights in education, which provided the opportunity for linguistic minorities to educate themselves and maintain their identity. The public national radio and television channel, and public local media in municipalities where the minorities constituted $20 \%$ of the population, broadcasted programs in minority languages for a set amount of time. The state also financed the pub- 
lication of one newspaper in Albanian and one in Turkish. A national theatre of ethnic minorities in Skopje, which offered Albanian and Turkish drama as well as some cultural-artistic associations and groups, was financed by the state budget.

The right to education in the language of minorities was guaranteed in primary and secondary schools. Instructions in the mother tongue have been recognized as a successful approach for the inclusion of linguistic minorities in the educational system, as well as for the protection of their cultural heritage and identity. In practice, primary education was offered in Macedonian, Albanian, Turkish and Serbian, while in secondary schools the languages of instruction were Macedonian, Albanian and Turkish. The reasons for organizing education in the mother tongue of only these and not the other minorities were due to the limited number of teachers and limited economic resources.

But Albanians in Macedonia also demanded higher education in their language, as well as the state-funded Faculty of Pedagogy in Albanian, with aims to "produce" Albanian language-teachers for primary and secondary schools. These demands for higher education in Albanian were intensified after 1995 when the University of Pristina was closed by Slobodan Milošević's authoritarian government. Some professors who lost their jobs in Kosovo came to Macedonia and attempted to open an Albanian language university in Mala Rečica, a village near Tetovo. This university functioned illegally at the beginning.

In 2000 the first university in the Albanian languagethe South East European University-was established with assistance from OSCE (the Organization for Security and Co-operation in Europe), the Council of Europe, and the United States. The Macedonian Government supported this university by providing the location and granting the use of land. Today, this university is regarded "as a model for multi-ethnic and multi-lingual higher education in South East Europe" (Xhaferi \& Ibrahimi, 2012, p. 674).

As explored, the first decade of Macedonian independence was characterized by divisive debates on language, especially minority-language education at university level; the registering of names at birth in minority languages; the use of topographical signs in a minority language; introducing Albanian language in state administration, etc.

Jenny Engström (2002, p. 6) points out that in this period:

Despite restrictions on the use of the Albanian language in higher education and political bodies, as well as de facto discrimination in employment, Albanians in Macedonia have by and large enjoyed extensive civil and political rights.

However, despite improvements in granting linguistic rights in 2000, "violent conflict between Macedonian se- curity forces and armed Albanian extremists in the country" (Brunnbauer, 2002, p. 2), or a "mini-war" as it is called by Engström (2002, p. 11), began in Macedonia in January 2001, and ended in August 2001 with the Framework Agreement, which was signed by the leaders of the two biggest political parties in Macedonia, the leaders of the two political parties of the ethnic Albanians in Macedonia, as well as by the envoys from the EU and the United States, and the President of the Republic of Macedonia.

The implementation of the Framework Agreement needed constitutional and legislative changes. Hence, constitutional amendments were adopted in 2001. These amendments were followed by the adoption of more than thirty new laws and amendments on over thirty previous laws. Among the new adopted laws was the law on the use of languages.

\section{Linguistic Rights in Macedonia after 2001}

Constitutional amendments after 2001 introduced major changes in the official use of the languages of minority communities. The circumstances in which the Constitution was amended influenced the quality and clarity of new provisions addressing the issue of multilingualism, which caused different interpretations during their statutory regulation and everyday application.

The constitutional amendments make a difference to Macedonian language as the official language in the whole territory of the country, in the international relations of the Republic of Macedonia, and the official use of other languages spoken by at least $20 \%$ of the population. This threshold of $20 \%$ is fulfilled only by Albanian language. The Constitution defines the use of the Albanian language as official. Official, personal documents of citizens speaking other official languages are issued in that language, in addition to the Macedonian language.

Persons living in a unit of local self-government in which at least $20 \%$ of the population speaks an official language other than Macedonian may use that official language to communicate with the regional office of the central government. Such an office shall reply in that language, in addition to Macedonian. Also, any person may use any official language to communicate with ministries, which shall reply in that language in addition to Macedonian.

The Constitution also provides that in the state organs, any official language other than Macedonian may be used in accordance with the law. The provisions for official use of languages were included in different laws and in the special law for use of languages, adopted in 2008. The Parliament of the Republic of Macedonia "has opened its doors" for the Albanian language. Members of the Parliament and holders of public offices can speak in Albanian in the plenary meetings of the Parliament and during the work of the parliamentary commissions. The MPs can also use Albanian while presiding over parliamentary commissions. The laws that were adopted in 
the Parliament are translated and published in the Official Gazette of the Republic of Macedonia in Macedonian and Albanian language.

During the elections, all forms, ballot papers, and all electoral material for the municipalities in which at least $20 \%$ of the citizens speak an official language different from the Macedonian language were published in Macedonian and its Cyrillic alphabet, and in the other official language which is spoken by at least $20 \%$ of the population in the municipality and its corresponding alphabet. The name and surname of the person submitting the list of candidates, and the candidates of the elections printed on the ballot papers, are written in Macedonian and its alphabet as well as in the language and alphabet of the community to which they belong. With regard to the work of electoral commissions and electoral committees during the administration of elections, the municipalities in which at least $20 \%$ of the citizens speak an official language different to Macedonian, besides Macedonian language and its alphabet in official use, was the language and alphabet of the community with more than $20 \%$ of total number of the population in that municipality.

The official use of languages of minority communities in judicial procedures is also provided. Albanians in Macedonia, as participants in the criminal procedure, have the right to use their language in all phases of the procedure. The court would provide oral translation of the presentation by the Albanian participant in the procedure and of the documents and other written evidence. The court would provide written translation of the written material, which is of importance for the procedure or for the defense of the person who is accused. All other parties of the court proceedings, witnesses and participants in the procedure had the right to translation, free-of-charge, if they did not understand or speak the language in which the procedure is carried out in. The person participating in the court procedure would be advised of the right to translation. All pleadings and documents that are sent to the court can be sent in the Macedonian and Albanian language. If they are sent in Albanian language, they would be translated by the court. All documents that are sent to the parties of the proceedings (invitations, decisions, etc.) that speak Albanian are sent in their language in addition to the Macedonian language. Similar provisions are included in the laws on civil procedures.
The law also contained obligation for Macedonian Radio Television (MRT) to broadcast one TV channel and one radio channel in the Macedonian language, and one TV and one radio channel in minority languages. This further provides one channel on national TV in Macedonian, one in Albanian, and one in other minority languages.

Minority languages are also used in addition to the Macedonian language for the names of the streets, squares, bridges and other types of infrastructure in the municipalities in which they are official languages. Bilingual signs have a considerable psychological and symbolic importance. Language visibility takes the form of bilingual signs: road and traffic signs, street names, designations of official buildings, and general information:

Language visibility is an important policy measure because its official use and the generalization of minority language visibility has powerful (re)legitimization effect, which, in turn, impacts on people's attitudes. (Grin \& Vallancourt, 1999, p. 18)

The education in mother tongue in primary, secondary and university level is provided in the Macedonian and Albanian language. The primary education is provided in Macedonian, Albanian, Turkish, Serbian and Bosnian languages and secondary education in Macedonian, Albanian and Serbian languages. Some of the schools provide instructions in two or three languages (see Table 2).

At the local level, languages other than Macedonian are official if they are spoken by at least $20 \%$ of the population. According to this, Albanian, Turkish, Roma and Serbian are used as official languages. The local council can decide whether languages spoken by less than $20 \%$ of the population of a unit of local self-government can be used as official.

The implementation of official languages in municipalities is not without difficulty. All municipalities in which Albanians are in the majority successfully give services in the Albanian language. But in some of them, Macedonians complain that the demands and applications sent in the Macedonian language receive delayed responses compared with the applications sent in Albanian. Or, said in fewer words, local administration in some municipalities with the Albanian population in the majority is more inefficient when responding to applications in the Macedonian language. The situation is the

Table 2. Primary and secondary schools according to the language of instructions in 2015-2016.

\begin{tabular}{lllll}
\hline Language & $\begin{array}{l}\text { Number of primary } \\
\text { schools }\end{array}$ & $\begin{array}{l}\text { Number of pupils in } \\
\text { primary schools }\end{array}$ & $\begin{array}{l}\text { Number of secondary } \\
\text { schools }\end{array}$ & $\begin{array}{l}\text { Number of pupils in } \\
\text { secondary schools }\end{array}$ \\
\hline Macedonian & 725 & 119,550 & 98 & 54,858 \\
Albanian & 294 & 59,437 & 36 & 23,308 \\
Turkish & 64 & 5,591 & 12 & 1,574 \\
Serbian & 5 & 258 & $/$ & $/$ \\
Bosnian & 3 & 283 & $/$ & $/$ \\
\hline
\end{tabular}

Source: State Statistical Office of the Republic of Macedonia (2017). 
opposite in some municipalities in which Macedonians are the majority.

The municipality of Suto Orizari is a unique unit of local self-government in which the majority of the population are Roma and their language is one of the official languages. It is also a unique municipality in which the majority population doesn't use their mother tongue in communication with the municipality. The written communication of the Roma population with the local administration is in the Macedonian language. The main reason for this is due to the fact that most of the people do not know how to write in the Roma language because in primary (and secondary) schools they were educated in the Macedonian language. The presumption that the competence level of speakers of the ethnic minority language is one of the factors of its use in the official communication can be proven in this municipality.

The reasons for improper implementation of legal norms for official languages on local level are many: deficit of finances for providing services in the language of the minorities; lack of political understanding of the need and priority to offer services in minority languages; deficiency of demands for minority language use in contact with the local government; and lack of political will.

\section{Language Issues and Political Mobilization in Macedonia}

Since the independence of Macedonia, the implementation of linguistic rights in Macedonia has seen difficult negotiations and disputes. The analysis shows that the "Ohrid Framework Agreement further developed the constitutional and legal position of ethnic minorities in Macedonia." Macedonia has been given as an example for particular cases of "internationally orchestrated diversity-management efforts featuring the intensive involvement of the international community" (Engl \& Harzl, 2009, p. 333).

The public opinion on the Framework Agreement was predominantly negative among Macedonian ethnicities in the beginning, as some Macedonian politicians:

Consciously articulated and at the same time manipulated widespread fears among ethnic Macedonians about their national identity, which many saw threatened by the terms of the Agreement. (Brunnbauer, 2002, p. 7)

The fear that the country's future existence is "under threat because the 'real' aims of the extremist Albanians were not the acquisition of rights but territories" has been raised (Brunnbauer, 2002, p. 8). These fears are fueled by the demands of Albanians "to be considered the second constitutive people of the Republic of Macedonia." They do not accept their "treatment as a minority" (Brunnbauer, 2002, p. 13).

With time, the acceptance and support of the Framework Agreement grew. But, despite that, nationalistic rhetoric was present in the electoral campaigns of certain political parties (of Macedonians and Albanians) in the period. In Macedonia, from 1991 until the last elections in 2016, political parties were divided on the basis of ethnic lines, i.e., the ethnicity dominated partisan organizations. The Albanians in Macedonia were mainly supporting political parties of ethnic Albanians. The interethnic mobilization in politics and civil society was weak. The reasons for political mobilization on the basis of ethnicity are several. According to Choudhry:

[U]nderlying political competition over officiallanguage status is economic competition over public sector employment, which fuels political mobilization on the basis of language." (Choudhry, 2009, p. 596)

We must keep in mind that "democratic nationhood is composed of three key, independent elements: civil society, the state and ethnicity" (Schöpflin, 2000, p. 35). "[W]hen civil society and the state are weak, as they are in Macedonia, ethnicity comes to dominate" (Engström, 2002, p. 18).

However, what was new for the elections of 2016 was that one of the major Macedonian political parties succeeded to mobilize ethnic Albanians and get their support in the elections.

A characteristic of the political system of Macedonia is that from 1991, all governments were coalitional, including at least one political party of ethnic Albanians, which advocated mainly ethnic demands of the Albanians in Macedonia. As a result of this, during negotiations for governmental coalitions, ethnic issues were on the agenda. As a result, the law on official use of languages was adopted after the elections in 2008 , and its changes were adopted after the elections in 2011. After the elections in 2016, political parties of ethnic Albanians demanded new changes in the law regarding the use of language in order to broaden the official use of their own language. The public perception, however, is that some of these demands for improving the status of the Albanian language are not an instrument of pragmatic intentions but a symbolic resource for political struggle and an attempt to increase the Albanian's political status in Macedonia.

\section{Conclusion}

There are many "historical lessons" where we are taught that the failure to properly respond to demands for improving ethnic rights can increase conflict in the state and can undermine social unity. Granting special rights to ethnic groups is necessary to enable their participation in political and economic decision-making, in order to implement substantive equality.

Unfortunately, Macedonia experienced these "historical lessons" on its own territory. Despite the fact that from 1991 Macedonia chose the regime of linguistic promotion, creating "positive" rights to key public services in 
minority languages, this was not considered a sufficient response to the demands of Albanian ethnic groups.

In the creation of language policy there is always controversy and there is never consensus on appropriate policies. Such experiences from developed democracies add additional burdens to formulating linguistic policies in Macedonia as a country in transition. The key characteristic of the whole period, from independence to the present, is that language policy in Macedonia has been driven by the mistrust between ethnic groups and at the same time, stimulated that mistrust.

This mistrust among ethnic groups has been fueled by the political immaturity of most politicians who are "locked in ethnic suites" and who intentionally obstruct building inter-ethnic peace in order to manipulate their electorate, keeping them in fear of the "enemies" from other ethnic groups.

The legal provisions regulating the official use of languages in Macedonia were as a result of difficult negotiations. Because of this, some of the provisions are unclear and open to different interpretations. In addition, the lack of political will to ensure proper implementation of the legal guarantees for use of all official languages on both sides: from central government and local government, and from ethnic Macedonian and ethnic Albanian officials, additionally fuels the ethnic mistrust.

Macedonia needs mature political leadership with a systematic approach to the accommodation of multilingualism in the country, as well as a desire to build trustful interethnic relations that are essential for the stability of the country.

\section{Conflict of Interests}

The author declares no conflict of interests.

\section{References}

Brunnbauer, U. (2002). The implementation of the Ohrid Agreement: Ethnic Macedonian resentments. Journal of Ethnopolitics and Minority Issues in Europe, 1, $1-24$.

Cardi, V. (2007). Regional or minority language use before judicial authorities: Provisions and facts. JEMIE, 6(2), 1-24.

Choudhry, S. (2009). Managing linguistic nationalism through constitutional design: Lessons from South Asia. I-CON, 7(4), 577-618.

De Varennes, F. (1997). Ethnic conflicts and language in Eastern European and Central Asian states: Can human tights help prevent them? International Journal on Minority and Group Rights, 5, 135-174.

Engl, A., \& Harzl, B. (2009). The inter-relationship between international and national minority-rights law in selected Western Balkan states. Review of Central and Eastern European Law, 34, 307-335.

Engström, J. (2002). Multi-ethnic or bi-nationalism? The framework agreement and the future of the Mace- donian state. Journal of Ethnopolitics and Minority Issues in Europe, 1, 1-21.

Friedman, V. (2012). The Balkan Sprachbund in the Republic of Macedonia today: "Eurology" as discontinuity and dialectology as continuity. Colloquia Humanistica, 1, 115-124.

Grin, F. (2003). Language policy evaluation and the European charter for regional or minority languages. New York: Palgrave Macmillan.

Grin, F., \& Vallancourt, F. (1999). The cost-effectiveness evaluation of minority language policies: Case study on Wales, Ireland and the Basque Country. Flensburg: ESMI.

Karajkov, R. (2011). Census fails in Macedonia. Retrieved from https://www.balcanicaucaso.org/eng/ Areas/Macedonia/Census-fails-in-Macedonia-105372

Kibbee, D. A. (2008). Minority language rights: Historical and comparative perspectives. Intercultural Human Rights Law Review, 3, 79-136.

Kolarova, R. (1993). Tacit agreements in Bulgarian transition to democracy: Minority rights and constitutionalism. The University of Chicago Law School Roundtable, 1(1), 23-51.

Korhecz, T. (2008). Official language and rule of law: Official language legislation and policy in Vojvodina Province, Serbia. International Journal on Minority and Group Rights, 15, 457-488.

Marácz, L. (2014). The politics of multilingual communication: Case studies and research agendas. In S. Craze \& F. Lempp (Eds.), Communicating conflict: A multidisciplinary perspective (pp. 45-62). Oxford: InterDisciplinary Press.

Marusic, S. J. (2011). Macedonian census commission resigns. Retrieved from http://www.balkaninsight. com/en/article/macedonian-census-commission-re signs

Patten, A., \& Kymlicka, W. (2003). Introduction. Language rights and political theory: Context, issues and approaches. In A. Patten \& W. Kymlicka (Eds.), Language rights and political theory (pp. 1-51). Oxford: University Press.

Perea, J. F. (1992). Demography and distrust: An essay on American languages, cultural pluralism, and official English. Minnesota Law Review, 77, 269-373.

Porter, K. (2003). The realisation of national minority rights. Macquarie Law Journal, 3, 51-72.

Schöpflin, G. (2000). Nations, identity, power: The new politics of Europe. London: Hurst \& Company.

State Statistical Office of the Republic of Macedonia. (2002). Census of population, households and dwellings in the Republic of Macedonia 2002-Bookl. Retrieved from http://www.stat.gov.mk/Publikacii/ knigal.pdf

State Statistical Office of the Republic of Macedonia. (2017). Primary, lower secondary and upper secondary schools at the end of the school year 2015/2016. Retrieved from http://www.stat.gov.mk/ Publikacii/2.4.17.05.pdf 
Tully, J. (2001). Introduction. In A.-G. Gagnon \& J. Tully (Eds.), Multinational democracies (pp. 1-34). Cambridge: University Press.

Wodak, R., Krzyźanowski, M., \& Forchtner, B. (2012). The interplay of language ideologies and contextual cues in multilingual interactions: Language choice and code-switching in European Union institutions. Language in Society, 41, 157-186.
Xhaferi, H., \& Ibrahimi, M. (2012). The implementation of multilingualism at the SEE University: A model for the multicultural Balkans. Jezikoslovlje, 13(2), 667-677.

Zappettini, F., \& Comanaru, R. (2014). Bottom-up perspectives on multilingual ideologies in the EU: The case of a transnational NGO. Journal of Contemporary European Research, 10(4), 402-422.

\section{About the Author}

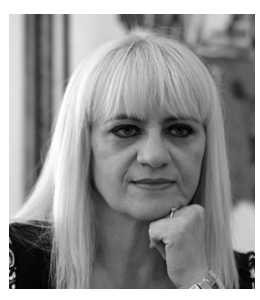

Renata Treneska-Deskoska (PhD) is Professor of Constitutional Law and Political Systems at the Law Faculty "Iustinianus Primus" in Skopje, Macedonia. She completed her PhD in legal studies at the University of Ljubljana, Slovenia. Her research focuses on human rights, multilingualism, and organization of powers. She worked on many projects funded by UNDP, OSCE, NDI, COLPI/PILI and DIFID. In 2012 she was elected a member of the ODIHR Advisory Panel of Experts on Freedom of Religion or Belief. 